\title{
KRZYŻ W SZKOLE PUBLICZNEJ W ORZECZNICTWIE EUROPEJSKIM
}

W dniu 3 listopada 2009 r. Europejski Trybunał Praw Człowieka w Strasburgu orzekł jednogłośnie (głosami 7 sędziów II Wydziału) o pogwałceniu przez Włochy art. 2 Protokołu nr 1 do Konwencji o Ochronie Praw Człowieka i Podstawowych Wolności ${ }^{1}$ w powiązaniu z art. 9 Konwencji², z powodu „przymusowej ekspozycji symbolu określonego wyznania" ${ }^{3}$, w tym wypadku krzyża, w salach lekcyjnych szkół publicznych. Orzeczenie to stanowi kolejne nawiązanie do wieloletniej, klarownej i stabilnej linii orzeczniczej ETPC w sprawach dotyczących problemu prezentowania symboli religijnych $\mathrm{w}$ przestrzeni publicznej państwa laickiego ${ }^{4}$. W dniu 2 marca 2010 r. zespół 5 sędziów Wielkiej Izby (II instancja ETPC) przyjął wniosek państwa włoskiego o przekazanie sprawy do

\footnotetext{
Dr Jacek FALSKI jest adiunktem w Zakładzie Prawa Konstytucyjnego i Badań Europejskich Instytutu Nauk Prawnych PAN w Warszawie. inp@inp.pan.pl
}

\section{- . . •}

Protokół dodatkowy nr 1 do Konwencji art. 2 mówi: „Nikt nie może być pozbawiony prawa do nauki. Wykonując swoje funkcje w dziedzinie wychowania i nauczania, Państwo uznaje prawo rodziców do zapewnienia tego wychowania i nauczania, zgodnie z ich własnymi przekonaniami religijnymi i filozoficznymi". M.A. Nowicki, Wokót Konwencji Europejskiej, Warszawa 1992, s. 191.

2 Europejska Konwencja o Ochronie Praw Człowieka i Podstawowych Wolności, Dz. U. Nr 61/1993, poz. 284 Art. 9 Konwencji mówi: „1. Każdy ma prawo do wolności myśli, sumienia i wyznania; prawo to obejmuje wolność zmiany wyznania lub przekonań oraz wolność uzewnętrzniania indywidualnie lub wspólnie z innymi, publicznie lub prywatnie, swego wyznania lub przekonań przez uprawianie kultu, nauczanie, praktykowanie i czynności rytualne. 2. Wolność uzewnętrzniania wyznania lub przekonań może podlegać jedynie takim ograniczeniom, które są przewidziane przez ustawę i konieczne w społeczeństwie demokratycznym z uwagi na interesy bezpieczeństwa publicznego, ochronę porządku publicznego, zdrowia i moralności lub ochronę praw i wolności innych osób".

3 Orzeczenie ETPC z 3 XI 2009 w sprawie Lautsi v. Wtochy, § 57.

4 Zob. np. J. Falski, Państwo laickie wobec problemu prezentowania symboli religijnych, "Państwo i Prawo” nr 6/2006, s. 73; tenże, Europejskie kryteria wolności sumienia i wyznania a islam, "Państwo i Prawo" nr 9/2008, s. 57; M. Levinet, Société démocratique et laicité dans la jurisprudence de la Cour européenne des droits de l'homme, [w:] Laicité, liberté de religion et Convention européenne des droits de l'homme, red. G. Gonzales, Bruxelles 2006, s. 82 i n.; G. Gonzales, L'école publique comme sanctuaire laïque selon la Cour Européenne des Droits de l' Homme, "Revue trimestrielle des droits de l'homme", nr 82/2010, s. 467 i n.; Konwencja o Ochronie Praw Człowieka i Podstawowych Wolności, Komentarz do artykułów 1-18, Tom I (red.) L. Garlicki, Warszawa 2010. 
Wielkiej Izby. Wniosek został złożony na podstawie art. 43 Konwencji. Wydaje się jednak, że sprawa nie ujawniła poważnych zagadnień dotyczących interpretacji bądź stosowania Konwencji lub Protokołu, a raczej poważną kwestię o znaczeniu ogólnym (art. 43-2 Konwencji).

Zanim przejdę do omówienia przedmiotowego orzeczenia i rozważań z nim związanych, chciałbym w skrótowy sposób opisać obowiązującą współcześnie we Włoszech koncepcję stosunku państwa do Kościołów i wyznań, przepisy konstytucyjno-prawne w tym zakresie i praktykę istniejącą w szkolnictwie i oświacie.

\section{PRAWNE RAMY STOSUNKÓW PAŃSTWA Z KOŚCIOLAMI WE WtOSZECH}

Art. 2 Konstytucji Republiki Włoskiej z 27 XII 1947 r. mówi: „Republika uznaje i gwarantuje nienaruszalne prawa człowieka zarówno jako jednostki jak i uczestnika grup społecznych, w których rozwija on swoją osobowość i wymaga wypełniania nie dających się uchylić obowiązków solidarności politycznej, ekonomicznej i społecznej"5;

art. 3 (ust. 1): „Wszyscy obywatele mają jednakową godność społeczną i są równi wobec prawa bez względu na płeć, rasę, język, religię, poglądy polityczne, położenie osobiste i społeczne";

art. 7: „Państwo i Kościół katolicki są, każde we własnym zakresie, niezależne i suwerenne. Ich stosunki są regulowane przez Pakty Laterańskie. Zmiany Paktów, przyjęte przez obie strony, nie wymagają procedury rewizji konstytucyjnej"

art. 8: „Wszystkie wyznania religijne są jednakowo wolne wobec prawa. Wyznania religijne inne niż katolickie mają prawo organizowania się według własnych przepisów, o ile nie są one sprzeczne z włoskim porządkiem prawnym. Ich stosunki z państwem są regulowane przez ustawę na podstawie porozumień z właściwymi przedstawicielstwami"7.

Konstytucja uznaje - jak widać - uprzywilejowaną pozycję Kościoła katolickiego.

Pakty laterańskie z 11 |l 1929 r., regulujące stosunki państwa z Kościołem katolickim, zostały zmodyfikowane umową konkordatową z 18 II 1984 r. ${ }^{8}$, która opiera się na wymogu układania wzajemnych stosunków przy poszanowaniu „niezależności i suwerenności” każdej ze stron i oparcia tych stosunków na zasadzie współpracy i zharmonizowania wszystkich regulacji wzajemnych stosunków z zasadami konstytucji i obowiązującym porządkiem prawnym, respektowania i nienaruszalności zagwarantowanych praw i wolności obywatelskich. Dokument unieważnił art. 1 traktatu laterańskiego, stanowiącego, że religia katolicka "jest jedyną religią państwa”. Od tego czasu Włochy uważa się za państwo laickie.

Umowa z 1984 r. przewiduje m.in., że państwo nadal będzie zapewniać nauczanie religii katolickiej we wszystkich publicznych przedszkolach, szkołach podstawowych i średnich. Uczniom (ich rodzicom) zagwarantowano prawo wyboru uczestniczenia lub nieuczestniczenia w tych lekcjach. Jakakolwiek decyzja w tym względzie nie powinna być powodem dyskryminacji ${ }^{9}$. Lekcje religii umieszczone są w planie zajęć szkolnych na

5 Wszystkie cytaty z Konstytucji za opracowaniem: Konstytucja Republiki Włoskiej, tłum. i wstęp Z. Witkowski, Warszawa 2004.

6 Pakty laterańskie zostały zmodyfikowane konkordatem z 18 || 1984 r., wprowadzonym ustawą z 25 III 1985 r.

7 W celu uregulowania bądź zweryfikowania tych stosunków uchwalono w latach 80. i 90. szereg ustaw na podstawie uprzednich umów, zawartych z przedstawicielstwami poszczególnych wyznań.

8 Projekt rewizji konkordatu laterańskiego nastąpił na złożony w 1965 r. wspólny wniosek Chrześcijańskiej Demokracji, liberałów i socjalistów.

9 Art. 9 umowy o zmianie konkordatu laterańskiego. 
pierwszej bądź ostatniej lekcji. Dla uczniów - jak wspomniałem - religia jest przedmiotem fakultatywnym. Dla tych spośród nich, którzy nie uczestniczą w tych lekcjach, jest wprowadzony, ale także (zgodnie z orzeczeniem Trybunału Konstytucyjnego) ${ }^{10}$ na warunkach fakultatywnych, alternatywny przedmiot (np. etyka). Nauczyciele religii są opłacani przez państwo. Pozostałe przedmioty szkolne nie są nasycone czynnikiem religijnym. Uczniowie innych wyznań (ich opiekunowie) mogą żądać nauczania swojej religii. Państwo jest zobowiązane zapewnić osobom wyznaczonym przez władze innych (niż katolickich) uznanych Kościołów możliwość takiego nauczania na terenie szkoły, przy czym jego koszta ponoszą władze danego Kościoła.

Istniejący dotąd we Włoszech obowiązek ekspozycji krzyża w szkolnych salach lekcyjnych wprowadzony został dekretem króla Piemontu - Sardynii z 15 IX 1865 r., zgodnie z brzmieniem którego "Każda - bez wyjątku szkoła ma obowiązek być wyposażona [...] w krzyż" (art. 140). Ten stan prawny został przejęty przez państwo włoskie w 1861 r. i dotąd nie był weryfikowany w tym zakresie. Także art. 118 dekretu królewskiego z 30 IV 1924 r. (Regulamin wewnętrzny zakładów szkolnych średniego stopnia w Królestwie) przewiduje, że „Każdy zakład szkolny musi posiadać flagę narodową, zaś każda sala szkolna obraz krzyża i portret Króla". Krzyże zostały także zaliczone do wyposażenia i materiałów niezbędnych w salach klasowych szkół" przez art. 119 dekretu królewskiego z 26 IV 1928 r. dotyczącego regulaminu służb nauczania podstawowego. Wzmocniona przez pakty laterańskie pozycja Kościoła katolickiego została osłabiona, cytowanymi wyżej, postanowieniami republikańskiej Konstytucji z 1948 r. i umowy konkordatowej z 1984 r.

Włochy podpisały i ratyfikowały (26 X 1955), bez zastrzeżeń, Konwencję Praw Człowieka, złożyły też deklarację o uznaniu prawa do skarg indywidualnych oraz o uznaniu jurysdykcji ETPC. Przepisy Konwencji stanowią integralną część prawa obowiązującego w tym kraju.

W takich oto okolicznościach prawnych powódka p. Lautsi, matka dwojga dzieci, mających w chwili zdarzenia 11 i 13 lat, zakwestionowała obecność krzyża w salach lekcyjnych szkoły publicznej, do której uczęszczały, powołując się na pogwałcenie zasady laickości, w duchu której życzyła sobie je wychowywać. Sąd Konstytucyjny, do którego się zwróciła, uznał brak swej kompetencji do rozstrzygnięcia kwestii konstytucyjności obowiązku narzuconego przez przepisy szczebla administracyjnego, zaś sąd administracyjny ${ }^{11}$ odrzucit jej skarge przeciwko decyzji dyrekcji szkoły o pozostawieniu krzyży, powołując się na obowiązujące prawo, tzn. wspomniane dekrety z 1924 i 1928 r. Trybunał Administracyjny w Aquili w orzeczeniu z 29 XI 2003 r. stwierdził m.in.: „Krzyż jest zarówno symbolem historii i kultury Włoch i w konwencji włoskiej tożsamości jak i symbolem zasad równości, wolności i tolerancji, a także laickości (sic! przyp. aut.) Państwa”12 i dalej: „Krzyż stał się jedną z wartości laickich Konstytucji włoskiej, utożsamiając wartości życia społecznego"13.

Niewątpliwie zaskakujące jest to uznanie przez Trybunał najsilniejszego chyba symbolu religii katolickiej za wartość laicką. Spłyca to, ogranicza i relatywizuje w sposób drastyczny znaczenie krzyża, sprowadzając jego moc do symbolu pop kultury. Jest to wybieg dotąd niestosowany, który sprowadza problem do banału, zmieniając płaszczyznę dyskursu, co nie wpływa oczywiście na jego skutki prawne. Strona skarżąca skorzystała z przysługującego jej prawa i wniosła skarge do ETPC, który wydał 3 XI 2009 r. orzeczenie w sprawie

10 Zob. „Prasa Zagraniczna o Kościele” 30 V 1989 r., s. 65.

11 Warto wspomnieć, że orzeczenie niższej instancji uwzględniło argumentację powódki, nakazując zdjęcie krzyży z sal lekcyjnych szkoły. Szerzej w: C. Panti, L'affaire des crucifix dans les écoles italiennes, „A.J.D.A.” 2004, s. 746 in.

12 Cytat z $\$ 13$ orzeczenia.

13 Cytat z $\$ 15$ orzeczenia. 
Lautsi v. Włochy. Wspomniane orzeczenie mieści się znakomicie w ramach orzecznictwa Trybunału, poprzez które usiłuje on upowszechnić prawdziwe wartości ideałów laickich, szczególnie w kontekście prawa do nauki z poszanowaniem przekonań religijnych i filozoficznych rodziców (art. 2 Protokołu dodatkowego nr 1 do Konwencji) w powiązaniu z prawem do wolności myśli, sumienia i wyznania (art. 9 Konwencji). Trybunał kontynuuje i rozwija swą linię orzeczniczą - spójną i co do koncepcji wyraźnie zakreśloną - dotyczącą neutralności światopoglądowej (w tym wyznaniowej) Państwa, w szczególności gdy spełnia ono funkcje edukacyjne.

Od 1984 r. (podpisanie "nowego" konkordatu) Włochy w sensie prawnym są państwem laickim, co prawda Konstytucja nie odnotowuje tego faktu wprost, ale zawiera klauzule o równouprawnieniu obywateli m.in. bez względu na wyznawaną religię, jednoczy wyznania w wolności wobec prawa, deklaruje niezależność i suwerenność państwa i Kościoła katolickiego przy jednoczesnym wykreśleniu z konkordatu postanowienia o tym, że religia katolicka jest jedyną religią państwa.

W orzeczeniu z 3 XI 2009 r. ETPC wskazał (w § 24), że włoski Trybunał Konstytucyjny w orzeczeniu z 20 XI 2000 r. "streścił swe dotychczasowe orzecznictwo, oznajmiając, że z fundamentalnych konstytucyjnych zasad: równości wszystkich obywateli bez względu na religię (art. 3 Konstytucji) i równości wszystkich wyznań wobec prawa (art. 8 Konstytucji) wynika obowiązek Państwa do zachowania równego dystansu i bezstronności; bez względu na liczbę wyznawców tej czy innej religii (zob. orzeczenia nr 925/88; 440/95; 329/97), czy na zasięg reakcji społecznej na pogwałcenie praw jednych bądź drugich (zob. orzeczenie 329/97)” i dalej, że „takie ujęcie równego dystansu i bezstronności jest odbiciem zasady laickości, którą Sąd Konstytucyjny rozciąga na pozostałe normy konstytucyjne i uznaje za zasadę z natury "najwyższą" (zob. orzeczenia nr 203/89; 259/90; 195/93; 329/97), charakteryzującą pluralizm Państwa".

\section{SZKOLA PUBLICZNA A RELIGIA W ORZECZNICTWIE EUROPEJSKIEGO TRYBUNALU PRAW CZŁOWIEKA}

Orzeczenie ETCP narzuca przestrzeganie zasady neutralności i w pewnych granicach ${ }^{14}$ także zasady równości, stanowiących rdzeń laickości. Trybunał pośrednio powołuje się na zasadę laickości poprzez odwołanie się do orzeczenia włoskiego Sądu Konstytucyjnego. ETPC stwierdza dalej (w § 56), że nie dostrzega, , jak eksponowanie w salach lekcyjnych szkół publicznych symbolu słusznie utożsamianego z katolicyzmem (religią dominującą we Włoszech) mogłoby służyć pluralizmowi edukacyjnemu, który jest istotnym elementem ochrony "społeczeństwa demokratycznego " w ujęciu Konwencji, pluralizmowi, którego obowiązywanie w prawie wewnętrznym uznał Sąd Konstytucyjny (zob. § 24)".

Trybunat wielokrotnie dawał do zrozumienia w swych orzeczeniach, że służba publiczna, stanowiąc emanację władzy państwowej, czy w skrócie państwa, musi odzwierciedlać jego neutralność wobec wszystkich religii. Funkcja edukacji publicznej mieści się w ramach służby publicznej w znaczeniu szerokim i podlega tym samym regułom, m.in. powinna prezentować punkt widzenia jednolicie pozbawiony wszelkich odwołań o cha-

\footnotetext{
14 Różnice w traktowaniu są dopuszczalne pod pewnymi warunkami. Zob. np. orzeczenie ETPC José Alujer Fernandez i Rosa Caballero Garcia v. Hiszpania (14 VI 2001); Association cultuelle Cha'ara Shalom ve Tsedek v. Francja (27 VI 2000), a wcześniej orzeczenie Komisji Europejskiej Praw Człowieka w sprawie Iglesia Boutista El Salvador v. Hiszpania (10 XII 1992).
} 
rakterze religijnym. Inne postępowanie może okazać się co najmniej krępujące dla tych, którzy określonej lub wręcz żadnej wiary nie podzielają.

W świetle orzecznictwa Trybunału szkoła publiczna W "społeczeństwie demokratycznym" jest miejscem neutralnym ze swej natury, w którym szanowane są wszystkie koncepcje religijne i filozoficzne, w których prozelityzm zwłaszcza o charakterze państwowym, nie może mieć miejsca.

W orzeczeniu Lautsi, ETPC przypomniał w 5 punktach w $\S 47$ synteze przesłanek, jakimi się kieruje, orzekając w sprawach tego typu, zawartą już zresztą we wcześniejszym orzeczeniu Wielkiej Izby (II instancja) z 29 VI 2007 r., w sprawie Folgero i inni v. Norwegia, a tutaj poddaną uzupełnieniom:

„a) Należy czytać dwa zdania artykułu 2 Protokołu nr 1, nie tylko biorąc pod uwage ich współzależność, ale także w szczególności w świetle artykułów 8, 9 i 10 Konwencji"15.

Zasada czytania zestawionego, obejmującego różne artykuły Konwencji została określona w orzeczeniu Kjeldsen i inni v. Dania z 7 XII 1976 r. i od tego czasu jest przytaczana w wielu orzeczeniach;

„b) Na podstawowym prawie do nauki zasadza się prawo rodziców do przestrzegania ich własnych przekonań religijnych i filozoficznych i pierwsze zdanie nie czyni, w większym stopniu niż drugie, rozróżnienia między nauczaniem publicznym i nauczaniem prywatnym. Drugie zdanie art. 2 Protokołu 1 ma na celu ochronę dostępności pluralizmu edukacyjnego, niezbędnego dla ochrony społeczeństwa demokratycznego - takiego, jakim pojmuje je Konwencja. Biorąc pod uwage siłę współczesnego państwa, cel ten powinien przede wszystkim być realizowany w nauczaniu publicznym";

„c) Szacunek dla przekonań rodziców musi być przestrzegany w ramach edukacji zdolnej do zapewnienia otoczenia szkolnego otwartego i popierającego raczej integrowanie niż wykluczanie, niezależnie od pochodzenia społecznego uczniów, ich wyznania religijnego czy pochodzenia etnicznego. Szkoła nie powinna być miejscem aktywności misjonarskiej czy wygłaszania kazań; powinna zaś być miejscem spotkania się różnych religii i przekonań filozoficznych, dzięki którym uczniowie mogą poznawać odmienne idee i tradycje" 16

Jak widać, otwarta dla wszystkich, na mocy szeroko rozumianego prawa do nauki, szkoła publiczna powinna charakteryzować się szacunkiem dla pluralizmu przekonań.

Określenie odpowiedzialności państwa na podstawie drugiego zdania art. 2 Protokotu nr 1 jest zupełnie nowe, dotąd niestosowane. Zawarte w orzeczeniu sformułowania: "otwarte otoczenie szkolne”, „popieranie raczej integrowania niż wykluczania” może być

\section{......}

15 Art. 2 Protokołu dodatkowego nr 1 do Konwencji cyt. w przyp. 1; art. 9 Konwencji cyt. w przyp. 2;

art. 8 Konwencji mówi: „1. Każdy ma prawo do poszanowania swojego życia prywatnego i rodzinnego, swojego mieszkania i swojej korespondencji. 2. Niedopuszczalna jest ingerencja władzy publicznej w korzystanie z tego prawa z wyjątkiem przypadków przewidzianych przez ustawę i koniecznych w demokratycznym spoteczeństwie z uwagi na bezpieczeństwo państwowe, bezpieczeństwo publiczne lub dobrobyt gospodarczy kraju, ochronę porządku i zapobieganie przestępstwom, ochronę zdrowia i moralności lub ochronę i wolność innych osób”, zaś art. 10, mówi że: „1. Każdy ma prawo do wolności wyrażania opinii. Prawo to obejmuje wolność posiadania pogladów oraz otrzymywania i przekazywania informacji i idei bez ingerencji władz publicznych i bez względu na granice państwowe. Niniejszy przepis nie wyklucza prawa Państw do poddania procedurze zezwoleń przedsiębiorstw radiowych, telewizyjnych lub kinematograficznych. 2. Korzystanie z tych wolności jako pociągające za sobą obowiązki i odpowiedzialność może podlegać takim wymogom formalnym, warunkom, ograniczeniom i sankcjom, jakie sa przewidziane przez ustawę i niezbedne w społeczeństwie demokratycznym w interesie bezpieczeństwa państwowego, integralności terytorialnej lub bezpieczeństwa publicznego, ze względu na konieczność zapobieżenia zakłóceniu porządku lub przestępstwu, z uwagi na ochronę zdrowia i moralności, ochronę dobrego imienia i praw innych osób oraz ze względu na zapobieżenie ujawnieniu informacji poufnych lub na zagwarantowanie powagi i bezstronności władzy sądowej.

16 Por. § 88 orzeczenia Folgero i inni v. Norwegia, wydanego przez Wielką Izbę 28 VI 2007 r., np. W: „Revue trimestrielle des droits de l'homme" nr 73/2008, s. 251-271. 
przyjmowane z pewnym zdziwieniem, zważywszy na orzecznictwo ETPC dotyczące kwestii noszenia przez uczniów symboli religijnych.

Taki kształt orzeczenia jest być może wyrazem osobistych przekonań przewodniczącej II Wydziału Trybunału, belgijskiej sędzi F. Tulkens, autorki kontrowersyjnego zdania odrębnego do orzeczenia wydanego przez Wielką Izbę w II instancji w głośnej sprawie Leyla Shain v. Turcja $(10 \text { XI } 2005 \text { r. })^{17}$;

„d) Drugie zdanie art. 2 Protokołu nr 1 zakłada, że państwo wypełniając przynależne mu obowiązki w przedmiocie edukacji i nauki, czuwa, żeby informacje czy wiedza znajdujące się w programach, były rozpowszechniane w sposób obiektywny, krytyczny i pluralistyczny. W zdaniu tym znajduje się zakaz działań mających na celu wpajanie poglądów (indoktrynacji), które mogą być uznane za nieszanujące przekonań religijnych i filozoficznych rodziców. Tu znajduje się nieprzekraczalna granica"18;

„e) Poszanowanie przekonań religijnych rodziców i wyznania dzieci oznacza prawo do wyznawania lub niewyznawania jakiejkolwiek religii. Wolność wyznania religii, jak i wolność niewyznawania religii (wolność negatywna), są objęte ochroną art. 9 Konwencji (zob. pod tym kątem art. 11, Young, James i Webster v. Wielka Brytania, 13 VIII 1981 $\S \S 52-57) "$.

Celem orzecznictwa ETCP dotyczącego zakresu spraw objętych art. 2 Protokołu nr 1 jest stworzenie ze szkoły publicznej miejsca neutralnego ze swej natury, właściwego dla chronienia i utrwalania wartości społeczeństwa demokratycznego. Po raz pierwszy orzeczenie ETCP dotyczące art. 2 Protokołu nr 1 (w cytowanym wyżej punkcie e) wyartykułowało explicite, iż ochroną objęte - jest w równym stopniu - przekonanie ateistyczne (a, co za tym idzie, agnostycyzm). Trudno dociec zresztą, czy obecność jakiegokolwiek symbolu religijnego jest bardziej dotkliwa dla ateistów czy raczej dla innowierców (rodziców i ich dzieci).

Najbardziej kontrowersyjną kwestią tego orzecznictwa jest przyjmowanie przez Trybunał szerokiego marginesu oceny przysługującej każdemu z państw dla właściwej - w jego przekonaniu - ochrony neutralności poprzez m.in. ograniczenia w gwarantowanej art. 9 Konwencji wolności uzewnętrzniania swego wyznania lub przekonań, przy czym ograniczenia te obejmują zarówno nauczycieli i pracowników administracji szkolnej, jak i uczniów. Należy przypomnieć, że całą tzw. służbę publiczną w państwie demokratycznym winna cechować neutralna powierzchowność. O ile państwo ma duży margines oceny w kwestii stopnia narzucenia neutralności użytkownikom instytucji sfery publicznej (nakazy, zakazy lub ich brak), o tyle zakaz prozelityzmu wobec pracowników służby publicznej jako funkcjonariuszy demokratycznego państwa powinien być w miejscu pracy absolutny, zależy to jednak od uznania władz państwa.

Mogą zatem istnieć (zależy to od obowiązujących w danym państwie przepisów) instytucje publiczne, np. szkoły, w których zarówno nauczyciele, personel pomocniczy etc., jak i uczniowie są zobowiązani do zachowania neutralności (zakaz noszenia chust, ostentacyjnych symboli religijnych itd.), ale mogą także działać instytucje czy urzędy publiczne, w których zakaz dotyczy tylko pracowników. Są jednak państwa, w których zakazy nie obowiązują żadnej ze stron.

W judykacie Lautsi Trybunał nie przywołał orzecznictwa dotyczącego noszenia chusty islamskiej w szkołach publicznych, choć przecież w tej sprawie mamy do czynienia

\section{-.....}

17 Aby prześledzić sprawę orzeczeń w sprawie L. Shain v. Turcja, zob. J. Falski, op. cit. w przyp. 4.

18 Te zalecenia ETPC nie zmieniły się od ponad 30 lat, por. orzeczenie Kjeldsen i inni v. Dania np. w ", Les grands arrêts de la Cour européenne des droits de I'homme" nr 56. 
z kolejnym desygnatem pojęcia „symbol religijny”. W § 50 orzeczenia ETCP wskazuje konieczność ochrony członków mniejszości przed naciskami wywieranymi przez większość należącą do określonego wyznania, ale powołuje się przy tym nie na ostatnie orzeczenia (np. we wspomnianej sprawie L. Shain v. Turcja z 2005 r.), ale na kontrowersyjne orzeczenie dawnej Europejskiej Komisji Praw Człowieka w sprawie Karadunam z 3 V 1993 r. ${ }^{19}$

Warto przypomnieć $w$ tym miejscu fragment (punkt f) orzeczenia Folgero z 2007 r. $^{20}$ Trybunał wskazuje w nim m.in., że „chociaż trzeba czasami podporządkować interesy osobiste grupowym, demokracją nie kieruje zasada stałej wyższości przekonań większości, narzuca ona równowagę, która zapewnia mniejszościom sprawiedliwe traktowanie i unikanie wszystkich nadużyć wynikających z dominującej pozycji".

Niektóre spośród Państw Stron Konwencji dopuszczają w ramach wspomnianego wyżej szerokiego marginesu oceny, obowiązkowe lekcje religii w szkołach publicznych. ETPC kontroluje w takich sytuacjach, czy państwo w zapewnianiu realizacji prawa do nauki nie podejmuje działań indoktrynacyjnych ${ }^{21}$.

W orzeczeniu Folgero ${ }^{22}$ Trybunał wyłożył explicite swój pogląd w tej materii:

\begin{abstract}
„Państwa dysponują szerokim marginesem oceny w kwestii wprowadzenia do programów szkolnych lekcji kultury religii; $W$ przypadku gdy lekcje te nie są zgodne z kryteriami obiektywizmu i pluralizmu określonymi przez Trybunał Europejski, muszą zostać podjęte stosowne środki, w celu zapewnienia przestrzegania przekonań rodziców, zgodnie z art. 2 Protokołu $\mathrm{nr} 1$, ale także samych dzieci, na mocy art. 9 Konwencji do chwili ukończenia przez nie stosownego wieku. W kwestii wyboru tych środków margines oceny państw znacznie się zawęża. Mogą tylko wskazać właściwy sposób zwolnienia ucznia z lekcji kultury religii (faktycznie najczęściej lekcji religii), który musi polegać na prawie lub obowiązku uczęszczania na lekcje zastępcze: w takim przypadku, na mocy art. 9 Konwencji, nie może być wymagane, żeby rodzice lub same dzieci były zobowiązane do uzasadniania swego wniosku o skorzystanie ze zwolnienia lub z lekcji zastępczych, w sposób ujawniający ich przekonania religijne lub światopoglądowe".
\end{abstract}

W sytuacji gdy istnieje możliwość wybrania - na wskazanych wyżej zasadach - przez rodziców (lub ucznia) lekcji alternatywnych (np. etyki), prawo z art. 2 Protokołu nr 1 jest według Trybunału - wystarczająco chronione ${ }^{23}$

Zakaz aktywnego prozelityzmu, polegającego na wywieraniu nacisku niezgodnego z przestrzeganiem przekonań i pluralizmem w społeczeństwie demokratycznym dotyczy tak samo Państwa, jak osób fizycznych wyposażonych w prerogatywy władzy publicznej (urzędnicy, nauczyciele, lekarze etc. w placówkach publicznych).

Trybunał orzekał w sprawach funkcjonariuszy skarżących się na zakaz noszenia w miejscu pracy (placówkach publicznych) symboli swej religii i upatrujących w tych zakazach pogwałcenia art. 9 Konwencji i każdorazowo oddalał skargę ${ }^{24}$, ale nie sformułował pozytywnego nakazu, zobowiązującego państwa do zawarcia w przepisach wewnętrznych zakazu eksponowania symboli religijnych w budynkach użyteczności publicznej, czy też w elementach stroju lub, szerzej, wyglądu funkcjonariuszy państwowych. Państwa, zgodnie z owym wspomnianym wyżej marginesem swobodnej oceny, pozostają wolne w wyborze dopusz-

\title{
$\cdots \cdots \cdot$
}

19 Decyzja z 3 V 1993, w sprawie Senay Karaduman, nr skargi 16278/90 Dn 74, s. 93. Komisja stwierdziła wówczas m.in., że „art. 9 Konwencji nie zawsze gwarantuje prawo do postępowania w obszarze publicznym w sposób dyktowany swymi przekonaniami”. W szczególności termin „praktykowanie” w rozumieniu art. 9 ust. 1, „nie oznacza każdego czynu uzasadnionego bądź inspirowanego wyznaniem lub przekonaniami”.

20 Por. przyp. 16

21 Por. przyp. 18

22 Por. przyp. 16.

23 Por. np. orzeczenia ETPC z 25 VI 2000, Jimenez Alonso i Jimenez Merino v. Hiszpania, i z 6 X2009, AppelIrgang v. Niemcy.

24 Por. np. orzeczenia: z 12 VII 1978, X. v. Wielka Brytania; z 25 V 1993, Kokkirakis v. Grecja, z 24 IX 1996, Manoussakis v. Grecja, z 15 || 2001, Dahlab v. Szwajcaria. 
czenia lub niedopuszczenia takich symboli w przestrzeni publicznej, przy czym z pewnością względy poprawności i sprostania wymogom państwa demokratycznego, w ujęciu konwencji, przemawiają za eliminacją wszelkich symboli religijnych z miejsc publicznych.

\section{KONSEKWENCJE ORZECZENIA LAUTSI v. WŁOCHY}

Przeanalizujmy, czy orzeczenie Lautsi przybliża nas do sformułowania przez Trybunał w przyszłości pozytywnego nakazu, wprowadzenia w przepisach wewnętrznych Państw Stron Konwencji, zakazu eksponowania symboli religijnych w przestrzeni publicznej.

Przedmiotowe orzeczenie rozszerza - jak się wydaje - obowiązek Państwa w zakresie przestrzegania neutralności. Trybunał wskazał w nim (§ 48) m.in., że ogólne zasady jego orzecznictwa „prowadzą do zobowiązania państwa do powstrzymania się od narzucania, nawet pośrednio, wiary w miejscach, gdzie przebywają osoby zależne od niego, a także w miejscach, gdzie są one szczególnie wrażliwe [vulnérable]" i dalej, że "skolaryzacja dzieci stanowi sektor szczególnie czuły, ponieważ w tym przypadku władcza rola państwa narzuca umysłom, którym brakuje jeszcze (zgodnie z poziomem dojrzałości dziecka) zdolności krytycznej, pozwalającej na zachowanie dystansu wobec przekazu wynikającego z uprzywilejowanego wyboru, wyrażanego w kwestii religijnej przez Państwo".

Trybunał zwrócił uwage, że „niemożliwe jest niezauważenie krzyża w salach lekcyjnych” i „w kontekście edukacji publicznej trzeba koniecznie dostrzegać, iż jest on istotną częścią środowiska szkolnego i może być odtąd uznany za "silny symbol wewnętrzny" (Dahlab v. Szwajcaria nr 42393/98)". Przywołanie sprawy Dahlab wskazuje na uznanie przez Trybunał podobieństwa obu tych przypadków biernego prozelityzmu, stanowiącego pogwałcenie wymogów Konwencji w zakresie neutralności religijnej Państwa. W § 57 orzeczenia Lautsi ETPC nie pozostawia wątpliwości, że „przymusowa ekspozycja symbolu jednej religii, narzucona $w$ procesie pełnienia funkcji publicznej, w stosunku do sytuacji specyficznych podlegających kontroli rządowej, w szczególności w salach lekcyjnych, ogranicza prawo rodziców do edukowania dzieci zgodnie z ich przekonaniami, jak również prawo dzieci - uczniów, do tego aby wierzyć lub nie wierzyć".

Strona pozwana w sprawie Lautsi (Państwo włoskie) twierdziła, iż eksponowany w salach lekcyjnych krzyż miał ukazywać „pozytywny przekaz moralny wiary chrześcijańskiej, która przenika laickie wartości konstytucyjne, rolę religii w historii włoskiej, jak również jej zakorzenienie w tradycji państwa”, nadano mu więc „znaczenie neutralne i laickie z odwołaniem się do historii i tradycji włoskiej, głęboko związanej z chrześcijaństwem" (§ 51). Trybunał skonstatowat, że symbol krzyża ma wiele znaczeń, między którymi religijne jest przeważające” (§ 51) i dalej (w § 52 orzeczenia), że jego obecność „w salach klasowych stanowi użycie symbolu w specyficznym kontekście historycznym". Przypomniał też (§ 52), powołując się na orzeczenie Wielkiej Izby z 18 II 1999 r. w sprawie Buscarini i inni v. San Marino, że "ocena tradycjonalnego w sensie społecznym i historycznym charakteru tekstu używanego przez parlamentarzystów przy składaniu przysięgi, nie pozbawia go natury religijnej".

Orzecznictwo ETPC nie pozostawia złudzeń co do faktu, iż jego ideałem jest państwo całkowicie neutralne światopoglądowo, ale nie stawia ",kropki nad i”, relatywizując pozytywny obowiązek państw w tym zakresie i odwołując się do przynależnego im marginesu oceny.

W orzeczeniu Lautsi Trybunał stwierdził (W § 57), że: „stosownie do specyfiki sytuacji podniesionej w ocenie rządowej, o obowiązkowej ekspozycji symbolu określonego wyznania w pełnieniu funkcji publicznej" z powodu „ciążącego na państwie obowiązku prze- 
strzegania neutralności, w pełnieniu funkcji publicznej”, w kwestii „przymusowej ekspozycji symbolu", Trybunał orzekł brak neutralności państwa, zwielokrotniony elementem przymusu, wynikającego z postanowień dekretów z 1924 i 1928 r.

Należy więc wnosić, że jeśliby nie istniał ten obowiązek o charakterze przymusowym, umieszczenie krzyża nie byłoby zapewne w ocenie Trybunału niezgodne z Konwencją. Można przeprowadzić tu paralelę z obowiązkowymi lekcjami religii, faworyzującymi określone wyznania. Trybunał uznaje, że lekcje te mogą mieć charakter obowiązkowy, jeśli uczniowie, którzy tego sobie życzą mogą zostać z nich zwolnieni w sposób prawie automatyczny, w każdym razie bez nadmiernych formalności czy tłumaczeń zbyt dotkliwych dla zainteresowanych i godzących w sferę ich osobistych przekonań.

Poszczególne państwa i ich wymiar sprawiedliwości w różny sposób rozumieją te delikatne problemy. Nie po raz pierwszy też kultura, historia czy dziedzictwo państwowe są instrumentalizowane, w celu uczynienia akceptowalnym eksponowania symboli religijnych w miejscach publicznych. Takie przypadki zdarzają się we Francji czy Belgii dla obejścia zakazu noszenia chust w szkołach publicznych. Sądy administracyjne nie uznają jednak argumentacji, iż są to równie banalne jak kapelusz nakrycia głowy i podtrzymują zakazy władz administracyjnych ${ }^{25}$. Podobnie orzeka ETPC ${ }^{26}$. Trudno więc oczekiwać, aby stosowano inne miary w stosunku do przedmiotu równie symbolicznego co krzyż. Interesujące orzeczenie związane z tym problemem zapadło we Francji. Administracyjny Trybunał Apelacyjny w Nantes orzekł 4 II 1999 r. o nakazie zdjęcia krzyża wiszącego w sali rady miejskiej jednego z merostw. Wykonując to orzeczenie, mer umieścił krzyż w gablocie usytuowanej w sali otwartej dla interesantów. Niezadowolony z tej formy egzekucji nakazu sądowego powód ponowił swą skargę. W dniu 12 IV 2001 r. tenże Sąd orzekł, że „przechowywany z tytułu dziedzictwa historycznego gminy w gablocie ekspozycyjnej, zawierającej różne, pozbawione konotacji religijnej przedmioty [...] we wnętrzu otwartej dla publiczności sali [...] krzyż, nie może być postrzegany jako emblemat religijny umieszczony w miejscu publicznym".

Cieszący się dużą estymą w środowisku prawników Sąd Konstytucyjny w Karlsruhe wydał 16 V 1995 r. orzeczenie, w którym stwierdza m.in., że „przymus uczenia się pod krzyżem” może prowadzić do urazu, ale „nawet Państwo, które gwarantuje pełną wolność wyznania i przez to samo zmusza się do filozoficzno-religijnej neutralności, nie może odebrać przekonań i wartości przekazywanych przez historię i kulturę, na którym opiera się spójność społeczna i od których zależy wypełnianie jego własnych obowiązków". Dlatego też Trybunał zwrócił się do prawodawców w landach o znalezienie "rozsądnego kompromisu dla wszystkich". I tak np. Bawaria uchwaliła 13 XII 1995 r. ustawę, która potwierdziła symboliczną wartość krzyża na płaszczyźnie historycznej i kulturowej i narzuciła jego obecność w salach lekcyjnych „w szacunku dla wolności wyznania”. Ustawa wzięła pod uwage orzeczenie Trybunału i wprowadziła możliwość poszukiwania rozwiązań polubownych z dyrekcją szkoły, w przypadkach kontestowania wprowadzonego ustawą rozwiązania, pod warunkiem, że owa kontestacja pochodzić będzie od "osób obdarzonych autorytetem edukacyjnym”, odwołujących się do „kwestii wiary i materialistycznej koncepcji świata".

W 1999 r. Federalny Sąd Administracyjny wydał orzeczenie, na mocy którego krzyże zniknęły z sal lekcyjnych.

25 Obecnie istnieje już w Belgii, a od niedawna także we Francji całkowity zakaz noszenia chust w miejscach publicznych.

26 Np. orzeczenie ETPC z 30 VI 2009, Tuba Aktas v. Francja. 
Powracając do orzeczenia Lautsi i jego potencjalnych oddziaływań, należy zwrócić uwagę, że ETPC, odwołując się do neutralności państwa w „pełnieniu funkcji publicznych", wskazał całą służbę publiczną (szkoła publiczna jest tylko jednym z jej ogniw) jako pośredniego adresata swego judykatu i zawartych w nim wskazań.

Oczywiście są pewne miejsca publiczne i okoliczności, których owa neutralność nie dotyczy. I tak, użytkowane przez służby publiczne budowle historyczne i ich dekoracyjny wystrój, w którym „odniesienia religijne” nie są „elementem przeważającym” (§ 51), służby publiczne o charakterze wyznaniowym, np. dziekanaty, zakłady o różnym charakterze prowadzone przez Kościót, a finansowane przez państwo, cmentarze etc.

Z orzecznictwa strasburskiego można wnosić, że Trybunał uznaje model laickiego państwa za idealną okoliczność, umożliwiającą obywatelom korzystanie na równych zasadach z pełnej wolności wyznania. Laickość jawi się tu jako system relacji państwo-Kościół najbardziej sprzyjający rozwojowi wolności (jakiejkolwiek) religii poprzez dystans utrzymywany między nią a świeckim państwem²7.

Trybunał uznaje przy tym szeroki margines oceny poszczególnych Państw Stron Konwencji, dążąc jednak - zgodnie z wartościami w niej zawartymi - do prawnego celu, którym jest ochrona neutralności Państwa. Uniwersalizacja koncepcji laickości poprzez interpretacje art. 9 Konwencji i art. 2 Protokołu nr 1, zawarta w orzecznictwie Trybunału, prowadzi do jej rozpowszechnienia i oddziaływania na różne istniejące systemy relacji między państwem a Kościołami.

Od kilku dekad orzecznictwo ETPC dotyczące kwestii art. 9 Konwencji i 2 Protokołu nr 1 ujmowanych niezależnie lub łącznie z art. 14, zakazującym jakiejkolwiek dyskryminacji m.in. z powodów religijnych, przyczynia się do wzbogacenia wolności religii. Trybunał jasno dał do zrozumienia absolutną niezgodność - w świetle postanowień Konwencji - między ustrojem teokratycznym a demokratycznym, pozostawiając jednak regulacje charakteru stosunków państwo-Kościół konstytucjom i prawu niższego rzędu Państw Stron. Rola mechanizmu Konwencji jest z założenia subsydiarna ${ }^{28}$.

Wolność religii zakłada w wersji minimalnej tolerancję, szacunek dla religijnego pluralizmu i neutralności państwa, szczególnie ważną wtedy, gdy ma ono charakter quasi-wyznaniowy. Dla każdego państwa neutralność ma wymierny koszt, prowadząc do zweryfikowania, czy zakwestionowania stosunków z dominującym Kościołem, ale nieuchronna droga jej wprowadzenia wiedzie przez odrzucenie kolejnych kompromisowych rozwiązań, zwłaszcza w miejscach, gdzie skondensowana jest szczególna wrażliwość [vulnérabilité] społeczeństw - edukacja, służba zdrowia, sądownictwo, domy opieki etc.

Chodzi więc chociaż o tzw. neutralność względną, która wymaga ze strony państw mniej „poświęceń”, a gwarantuje wolność wyznania (art. 9.1 Konwencji) z klasycznymi tylko ograniczeniami (art. 9.2 Konwencji).

Art. 9 Konwencji i drugie zdanie art. 2 Protokołu nr 1 odwołują się do wspólnego ideału, zabraniającego państwu indoktrynowania, jak również ujawniania swych - ewentualnie - preferencyjnych, względem określonego wyznania, wyborów.

Praktyka eksponowania krzyża w miejscach publicznych występuje w wielu państwach europejskich, jednak ETPC podjął ten problem dopiero w sprawie Lautsi, stwierdzając, że umieszczenie krzyża w salach szkolnych narusza Konwencję. Wielokrotnie zaś wypowiadał się, o czym była wyżej mowa, z taką samą konkluzją o innym desygnacie pojęcia "symbol religijny", np. chuście islamskiej. Żadne z tych orzeczeń nie stworzyło dla państwa

27 Zob. P.H. Prélot, Definir juridiquement la laïcité, [w:] G. Gonzales, op. cit. w przyp. 4, s. 121.

28 Zob. np. Handyside v. Wielka Brytania, orzeczenie z 7 XII 1976, seria A, nr 24 § 48. 
pozytywnego obowiązku wprowadzenia ogólnych przepisów, a tylko uświadomiło, jak będą - z dużą dozą prawdopodobieństwa - rozpatrywane podobne sprawy indywidualne (oczywiście zawsze z uwzględnieniem tła stosunków i sytuacji panujących w danym państwie). Komentarze do takiej linii orzeczniczej rozkładają się od akceptujących, „[...] nie jest stosowne uruchamianie orzecznictwa europejskiego dla stwarzania szczelnego rozdziału między polityką a religią" 29 , po krytyczne: „ETPC [...] odwołuje się do marginesu oceny państw, która pozwala mu czasami "umywać ręce" od brania odpowiedzialności"30.

Margines oceny pozwala państwu dokonać wyboru co do formy organizacji nauczania religii: nie mówić o niej w ogóle, mówić mało, zawrzeć wiedzę o faktach religijnych w ramach nauczania innych przedmiotów (rozwiązanie zalecane we Francji) bądź umieścić w programie odrębne lekcje religii typu katechetycznego. W ostatnim przypadku szkoła (państwo) musi zapewnić realny system zwolnień, który może zostać poddany ocenie ETPC pod kątem jego adekwatności do wymogów Konwencji w zakresie neutralności państwa demokratycznego.

Orzeczenie Lautsi jest wpisane w logiczny ciąg linii orzeczniczej w sprawach dotyczących eksponowania symboli religijnych, przy czym odnosząc się wprost do szkolnictwa publicznego (prywatnego nie dotyczy), w sposób pośredni daje do zrozumienia, że dotyczy całego obszaru służby publicznej. Nie zmienia jednak sytuacji co do zasady i nie nakłada na państwo ogólnego pozytywnego obowiązku zmiany przepisów w tym zakresie, pozostawiając to w skali ogólnopaństwowej jego uznaniu. Bez wątpienia jednak orzeczenie wskazuje, że Włochy nie miały - w kontekście postanowień Konwencji - słuszności, kontynuując uzewnętrznianie swej stronniczości światopoglądowej w sferze publicznej, poprzez eksponowanie symbolu określonej religii, a więc zachowanie typowe dla państwa wyznaniowego.

\section{THE CRUCIFIX IN THE PUBLIC SCHOOL CLASSROOM IN EUROPEAN COURT RULINGS}

\section{Summary}

Lautsi v. Italy was an important court case that was tried at the European Court of Human Rights in Strasbourg. The subsequent ruling on 3rd November 2009 noted that the display of religious symbols (i.e., the crucifix in Italian public school classes) is contrary to Article 2 of the 1 st Protocol of the European Convention on Human Rights. This decision which went against Italy is in line with other judgments in similar cases, and seems to be promoting the European public school as a place of confessional neutrality where the goal is to cultivate secular values of a democratic society in pupils.

The European Court of Human Rights thus clearly supports the idea and principles of secularism and the impartiality of the state. However, the ruling did not impose any obligation to undertake adequate legal solutions or verify the existing law, leaving each member state a level of freedom to make opinions and final decisions on their own. The Lautsi v. Italy judgment had an indirect influence on the entire public service sphere, of which the public school is just one link of a chain. Yet Italy filed an appeal and the case was referred to the Court's Grand Chamber. Its hearing is to be held on June 30,2010 . The legal ramifications of this ruling therefore remain an important debate in Europe.

Keywords: the European Court of Human Rights, crucifixes in the classroom, human rights

29 M. Levinet, op. cit., w przyp. 4, s. 112

30 G. Gonzales, op. cit., nr 82/2010, s. 483 